\title{
Career Path Development and its Impact on Organizational Citizenship Behavior in Greater Amman Municipality
}

\author{
Khaled Mahmoud Al-Shawabkeh ${ }^{1}$ \\ ${ }^{1}$ Management Department, The World Islamic Science and Education University (WISE), Jordan \\ Correspondence: Khaled Mahmoud Al-Shawabkeh, Management Department, The World Islamic Science and \\ Education University (WISE), Tabarbour, P.O Box 1101, Postal Code 11947, Amman, Jordan
}

Received: November 4, 2016

Accepted: December 17, 2016

Online Published: February 22, 2017

doi:10.5539/ijbm.v12n3p79

URL: https://doi.org/10.5539/ijbm.v12n3p79

\begin{abstract}
This study aimed to measure the impact of career path development (career planning and career management) on organizational citizenship behavior in Greater Amman Municipality. The study population is consisted of (122) managers at middle managerial level in greater Amman municipality. The current study used simple random sample. Based on this, a total of (90) respondents were targeted, from which a total of (85) answered questionnaires were retrieved, of which (3) were invalid. Thus, (82) answered questionnaires were valid for analysis. The questionnaire consisted of (30) items of close ended response type about independent and dependent variables. The study used the statistical analysis SPSS (Statistical Package for Social Sciences); for testing the hypotheses through regression analysis.

The results of testing hypotheses have shown that there is There is a statistically significant impact at level $(\mathbf{P}<=$ 0.05) of career path development with its dimensions: (career planning and career management) on organizational citizenship behavior (OCB) in Greater Amman Municipality. And illustrated that (65.9\%) of the explained variation in organizational citizenship behavior in greater Amman municipality can be accounted for career path development with its dimensions: (career planning and career management). The study recommended that organization should use reward systems that support the organization's career development strategy and enhancing the OCB.
\end{abstract}

Keywords: Career Path Development, Career Planning, Career Management, Organizational Citizenship Behavior (OCB), Greater Amman Municipality.

\section{Introduction}

In an unpredictable and uncertainty environment with expanding requirement for skilled labor, organizations are gradually more viewing career path development as a practical opportunity to recruit and keep capable workers. Employees' awareness of the upcoming plan of their associations for them, they tend to be more commitment. Therefore, career path development seems as a vital practice for attaining better employees' commitment and collaboration. On the other hand, career path development is not a once action for an association. Considerably, it is an ongoing progression for appraising employees' performance and capabilities.

Work life environment has been changed. The organizational environment is highly turbulent and complicated, consequential in uncertain and conflicting career indication. Personnel, possibly in self- defense, are varying some of their career- related viewpoints and behaviors and becoming undecided about their needs and plans for career development. Comprehending career development is an organizational requirements; it is an assessment of two processes: how employees plan and implement their own career objectives (career planning); and how organizations design and implement their career development programs (career management) (Bernadine, 2010, 295).

Career development is critical for realizing career planning and management. It consists of actions undertaken by workers (career planning) and the organization (career management); to encounter career objectives and job necessities (Singh, 2011, 235).

The importance of human resource development today is optimum understood in view of modification that have risen in the model of work skills that individuals have over their existence. This model is entitled as a career (Stewart \& Brown, 380). Nowadays career is recognized as protean career; which is derived from self- direction 
with the target of psychological accomplishment in labor. Human resources catch main responsibility for managing their careers (Noe, Hollen, John, Gerhrty, \& Wright, 2012 408).

Organizational citizenship behavior (OCB) was original presented by (Organ, 1988). He described Organizational citizenship behavior as a worker's optional behaviors that immediately support the effectual implementation of productivity (Huak, Pivi \& Hassan, 2015). Organ stated five elements of Organizational citizenship behavior (OCB): Altruism, Courtesy, Sportsmanship, Conscientious, and Civic virtue. This paper adopted the five elements of OCB given by Organ.

The current study aims to explore the impact of career path development on organizational citizenship behavior (OCB) in Greater Amman Municipality.

\section{Importance of the Study}

This part presents two approaches in which the current study is essential. Firstly, the scope of the study concentrates on the variables whose relationships with each other are investigated. It shows why Career path development is choosen as the variable that have an effect on OCB. Secondly, the practical significance; especially that the study population (Greater Amman Municipality) concerns about developmental strategies and attempt to be competitive.

This study aims to clarify career path development and organizational citizenship behavior. Consequently, this study is differentiated in dealing with these variables mutually. Thus, there is lack of researches that argue or investigate these variables together and the technique effect on each other. Consequently the findings of the existing study will enhance services sector in terms of awareness what has to be done regarding career path development dimensions that have to be adopted by decision makers to enhance organizational citizenship behavior.

\section{Problem Statement}

Proficient organizational citizens perform powerful and hard for their associations and its strategy. Investigation on organizational citizenship behavior has formed some vital approaches in organizational settings. Organizational citizenship behavior (OCB) is an essential aspect that can donate to the institutional sustainability. Accordingly, it is critical for associations to comprehend the variables that effect meaningfully and positively on OCB. On the other hand, a key matter arises, how to improve citizenship behavior in workers, which is a key question from the perspective of the researcher (Organ, 1988; Organ and Ryan, 1997).

The current study was conducted to address and investigate specified important matters about career path development and organizational citizenship behavior (OCB) in Greater Amman Municipality.

The study problem represents in the organizational citizenship behavior (OCB) in Greater Amman Municipality through examining the impact of career path development on organizational citizenship behavior. The research problem can be summarized in the main following question:

* What is the impact of career path development on organizational citizenship behavior (OCB) in Greater Amman Municipality?

\section{Hypothesis and Model of the Study}

In order to achieve the research objectives, the following main hypotheses and their sub-hypotheses are developed for testing:

$\mathbf{H}_{\mathbf{O} 1}$ : There is no a statistically significant impact at level $(\mathbf{P}<=0.05)$ of career path development with its dimensions: (career planning and career management) on organizational citizenship behavior (OCB) in Greater Amman Municipality.

$\mathbf{H}_{\text {O1.1. }}$ : There is no a statistically significant impact at level $(\mathbf{P}<=0.05)$ of career planning on organizational citizenship behavior (OCB) in Greater Amman Municipality.

$\mathbf{H}_{\mathbf{O 1 . 2}}$ : There is no a statistically significant impact at level $(\mathbf{P}<=0.05)$ of career management on organizational citizenship behavior (OCB) in Greater Amman Municipality. 
Independent Variable

Dependent Variable

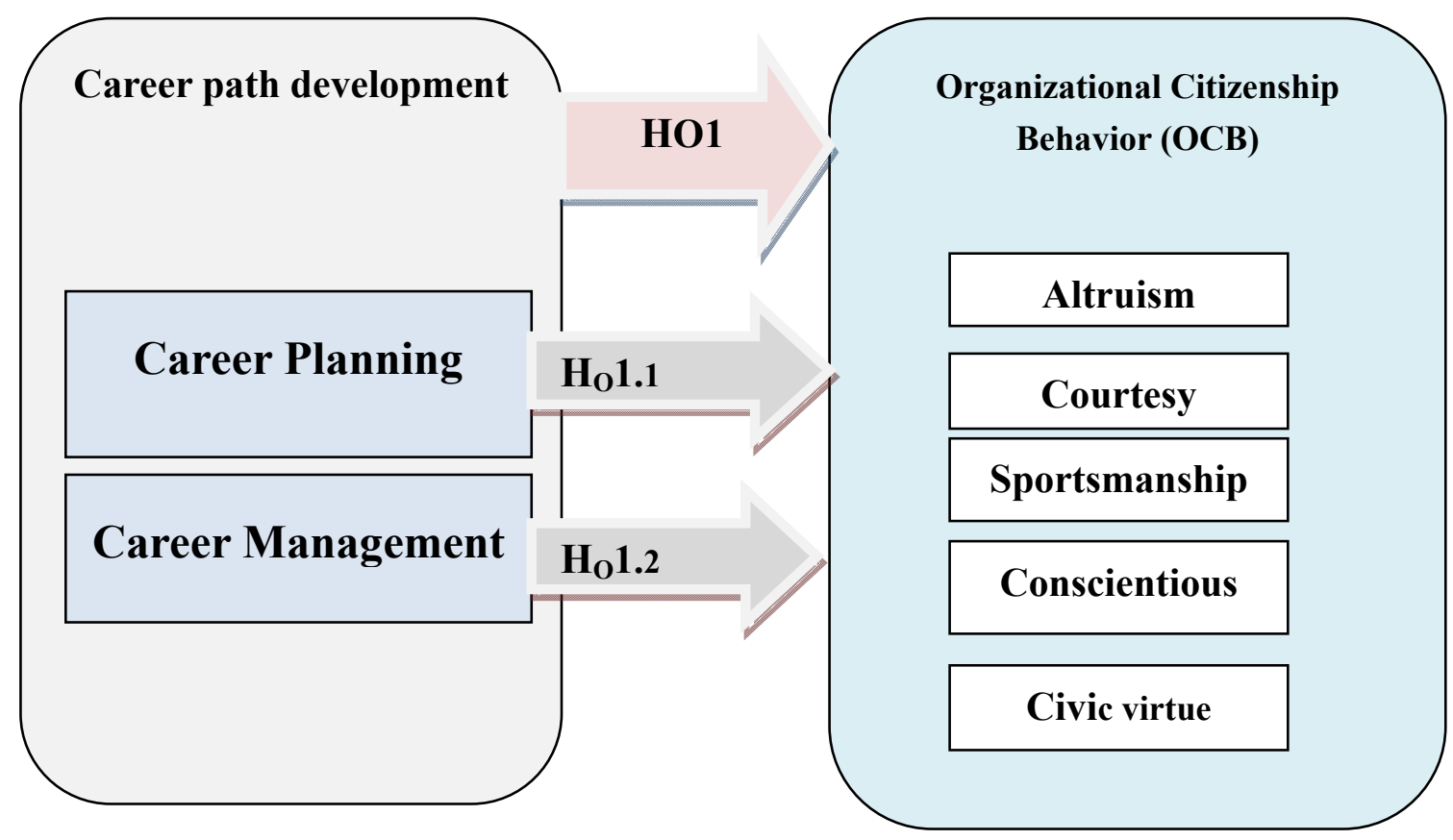

Figure 1. Model of Study

Reference: prepared by the researcher, depending on:

$\checkmark \quad$ Career path development: (Noe et al., 2012; Dessler, 2012; Bernardin, 2013).

$\checkmark \quad$ Organizational citizenship behavior (OCB): (Organ, 1997; Priyanka and Sripirabaa, 2016).

\section{Literature Review (Previous Studies)}

Priyanka and Sripirabaa (2016) study attempted to assess the impact of organizational citizenship behavior on intention to stay. The study reached that there was a positive impact for OCB on intent to stay. Thus, organizational citizenship behavior is fundamental for any organization as the same is associated with intention to stay amongst workers. Organizations ought to generate work environments that enhance responsibility among work teams.

Huak, Pivi, and Hassan (2015) study examined the impact of organizational citizenship behavior on employees' satisfaction, job commitment and turnover intentions. OCB dimensions included: Altruism, Conscientiousness, and Civic Virtue. This study was conducted in a private company in Malaysia. The results of the study showed that OCB dimensions are positively related to Job satisfaction and job Commitment, and negatively related to turnover intentions. Therefore OCB dimensions have a great effect on Job satisfaction, Job commitment and Turnover intentions which were detained responsible for employees' of dining restaurants in Malaysia. This study presented actions and approaches that will assist executives to recognize the advantages of OCB dimensions on Job satisfaction, Job commitment and turnover intentions.

Anwar and Gani (2015) study explored the effect of spiritual intelligence and its dimensions on organizational citizenship behavior through individuals who are working in manufacturing and service industries in Malaysia. The measuring instrument for organizational citizenship behavior (OCB) has adapted from the Podsakoff (1990) OCB scale. The five dimensions of OCB are: (Altruism, Conscientiousness, Civic Virtue, Courtesy, and Sportsmanship). The study reached that employee spiritual intelligence acts an essential role for generating organizational citizenship behavior among employees.

Musharaf, Alsaqry, and Obaid (2015) study determined the impact of big five personality factors (Neuroticism, Extraversion, openness to experience, Agreeableness, and Conscientionness) on organizational citizenship behavior (Altruism, Courtesy, Conscientiousness, Sportsmanship, and Compliance) among health service providers in Diwaniyeh general hospital. The study reached the existence of a direct impact of relationship statistically significant for each of the big five personality factors on organizational citizenship behavior. 
Turek and Turek (2015) study described and explained how human resource management practices: (recruitment and selection, motivation and rewards, and evaluation and development) and person organizational fit (P-O fit) are associated to organizational citizenship behavior (OCB). The study reached that there is a significant relationship connecting altogether studied variables. The study also concluded that employees' citizenship behaviors develop an imperative factor generating the efficiency of an association. The analyses in this study proposed that the behavior of individuals which is not directly related to the work responsibilities may on the other hand make a constructive environment inside a corporation.

Aslefallah and Badizadeh (2014) study examined the effect of organizational citizenship behavior with a scale which is composed of five dimensions by Organ (1988): Altruism, Conscientiousness, Civic Virtue, Fairness, and Responsibility. The study showed results that indicated a significant effect of organizational citizenship behavior on total quality management in addition to a significant effect of these components on organizational performance.

Kaya and Ceylan (2014) study investigated the impact of career development programs in organizations, and organizational commitment on employees' job satisfaction, an investigation is applied in a sample group working in various industries from various sectors operating in Istanbul province and Turkey. Results of this study indicated that career path development and organizational commitment have a partial impact on employees' job satisfaction.

Sharma and Jain (2014) study developed a scale for measuring organizational citizenship behavior; to standardize the scale; and to identify the factorial constitution of OCB in manufacturing organizations. The scale incorporates reported variables governing $\mathrm{OCB}$ activities in business organizations overcoming all critical dimensions of prosocial behaviors.

Shujaat, Aftab, Sana, and Ahmed (2013) study examined the relationship between career development and job satisfaction. The study is focusing on private banks in Karachi. The study concluded that there is a positive relationship between career development and job satisfaction. The study also showed that employees are satisfied with career development actions that are accessible at their associations.

Kimani and Gachunga (2013) study explored the impact of career management practices on employee engagement. The study concluded that there is an impact of career management practices: (mentoring, job posting, career planning, and performance review) on employee engagement. The study also concluded that employees be familiar with the afterward stage or point of their career in the study's population. The study showed that workers assist those willing to undertake career management courses and also the study concluded that there are guiding principles on the experiences and qualifications considered necessary to progress in ones' career, and last of all supervisors advices employees on how to plan their career and meet organizational requirements.

\section{Theoretical Framework}

\subsection{Career Path Development}

\subsubsection{Career}

Webster's dictionary spots terminology career as "one's life achieve or employment subsequent the stated job as life work". Career is "the job-related positions an individual over several years". Career is no uncomplicated sequence of employment in one or two organizations with an indication profession. Employees are now required to exchange accomplishment for training, growing, and development that remain them beneficial (Dessler, 2012).

Robbins and coulter (2009) describe career as a series of positions engaged by a worker. Also (Bernardin, 2010, 295) defines career as the progression of an individual's occupational actions and behaviors and related thoughts, ethics, and objective over the extent of individual's life.

Career is series of positions employed by individuals throughout the path of their work life. Workers have an ambition to enhance and develop their life and also a desire to recognize a significance of accomplishment (Singh, 2011, 223).

The expression "career" in organizations can be simply as the series of job experiences a member of staff may possess in the fullness of time. Employee's awareness may engage shifting from one work to another, career shift in associations must link between individual's and organizations' needs and objectives (Chebet, 2015, 15-16).

Career cannot be performed by chance; instead the developing world of work, it should be formed and directed through the workers than through the associations. Traditionally, careers take care of evolving in the situation of 
one or two organizations and to move forward in linear levels, as personnel moved upward by the steps of ranks in an association (Cascio, 2013, 379). Durai $(2010,193)$ defines career a series of upward actions in the career ranking accomplished by a member of staff. In general, it has been accomplished by better revenues and social security.

\subsection{Career Path}

Career path is the way that demonstrates a series positions in an incremental outline in which the worker moves and support through his career life in the association (Eliza, 2010,1). Career path defines as the succession of job experiences that position an individual for advanced rank jobs (Stewart and Brown, 2011, 381).

(Durai, 2010, 193) defines career path as an organized and purposeful development completed by an individual in his career in the whole work life. It shows the technique in which one's career has proceeded. Certainly, the career path is formed by aspects for instance, an individual's capabilities, aptitudes, skills, and the opportunities essentially accessible.

Cascio $(2013,395)$ mention that career path represents coherent and achievable series of positions that could be occupied, derived from analysis of what personnel essentially perform in an association.

\subsubsection{Career Path Development}

Career development is the conclusion originating from the interaction of individual career planning and organizational career management development (Bernardin, 2013, 295). Career development also defines as actions that assist individuals manage the sequence of their job experiences across their lines (Stewart and Brown, 2011, 376).

Employee development is most likely to encounter organizational requirements. A basic career development system entails four steps: self- assessment, reality check, goal setting, and action planning. At each step, both the worker and the association have tasks. The beneficial system will be if it is associated to the organizational objectives and requirements with managerial reinforcement and individuals' contribution, the following figure illustrates these above steps (Noe et al., 2012, 304).

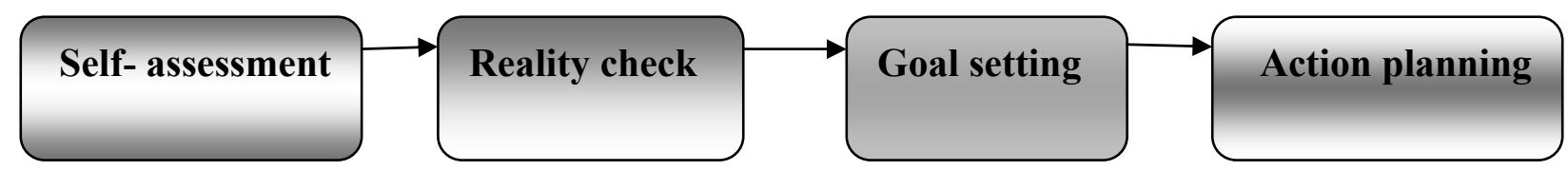

Figure 2. Steps of career development system

\subsubsection{Career Path Planning vs. Career Path Management}

Consequently, career planning must create a connection among individual's desires and organizational requirements and objectives. Individuals have to spot their capabilities and inspirations; to recognize their needs of development and training, associations must detect their requirements and opportunities (Eliza, 2010).

(Dessler, 2012) defines Career planning as "the purposeful progression through which an individual becomes conscious of individual abilities, benefits, knowledge, incentives, and other characteristics; and confirm action plans to reach certain objectives ".

Career path planning indicates an extraordinary valuable for all workers, particularly in view of barriers and speedy changes. Career path planning seeks to distinguish desires, objectives and opportunities for individual career and the realization of developing human resource agenda to support that career (Eliza, 2010).

Bernardin $(2010,265)$ defines career path planning as "a intentional process for appropriate conscious of self, consequences, limitations, options, and opportunities; recognizing career- associated with objectives; and instruction of work. Career path development has two approaches: career planning (individual responsibility) and career management (organization responsibility).

Career management is a continuing progression of implementing, preparing, and checking career plans assumed by the individual unaccompanied or consistent with the organizational career arrangement (Bernardin, 2010, 295). Also, career management is deliberated to be an organizational development but applies and monitors by individuals isolated or classified as institutional career scheme (Singh, 2011, p. 225).

Bernardin $(2010,295)$ demonstrated that career planning consists of four sub processes: "occupational choice; organizational choice; choice of job assignment; and career self - development". And also, Career management 
consists of four sub processes: "recruitment and selection; human resource allocation; appraisal and evaluation; and training and development". These categories and sub processes declared in the following figure:

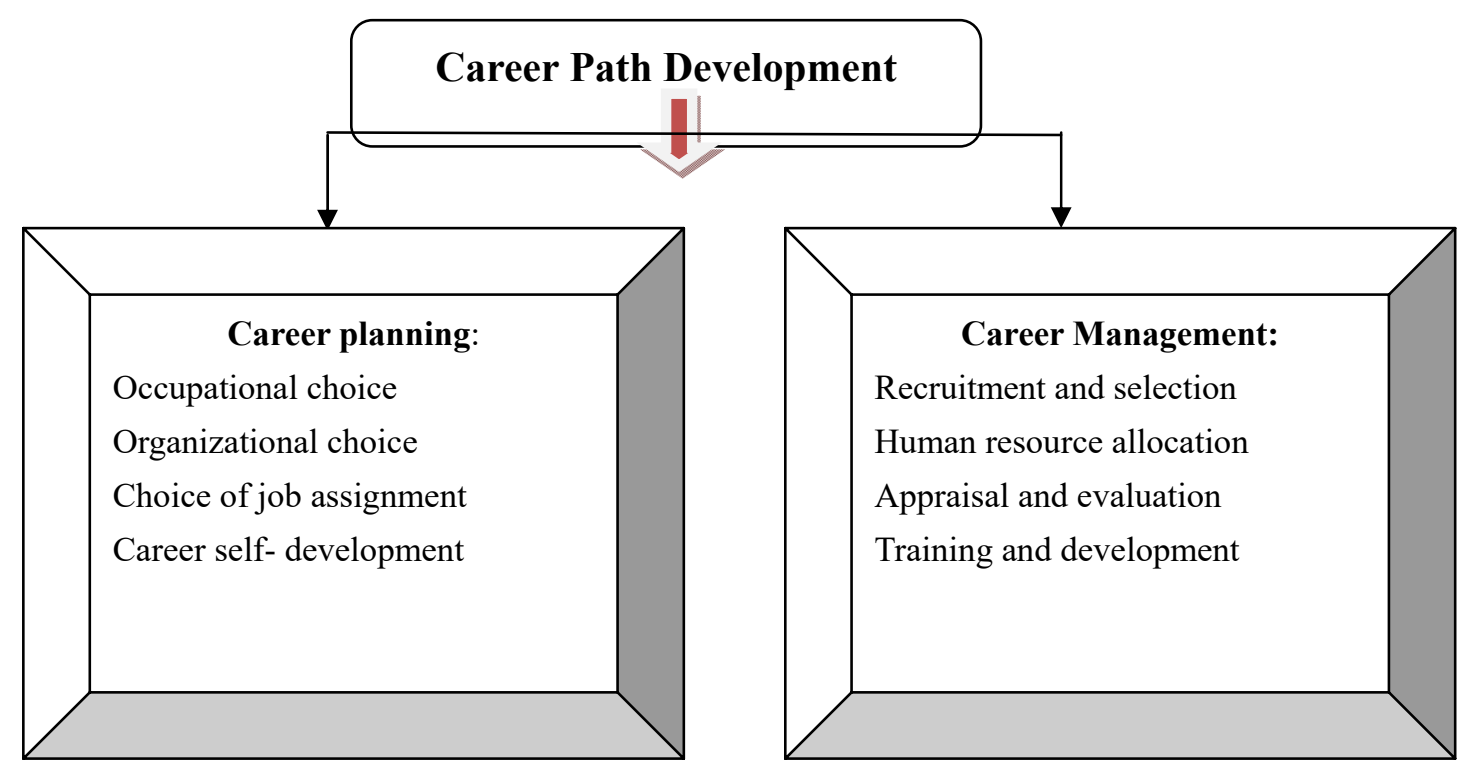

Figure. 3. Career path development categories

Source: Gutteridge, T. G., career path development systems: the state of practice in career development in organizations, D.T Hall and associates. / From (Bernardin, 2010, 295).

\subsection{Organizational Citizenship Behavior (OCB)}

Organ (1988) defined organizational citizenship behavior (OCB) as "individual behavior that is optional and voluntary, not directly to any official compensation and that in collective support effectual performance of an association ".

Organizational citizenship behavior (OCB) can be distinct like intended actions engaged through the workers on their individual plan with the purpose of assistance other workers and donate to commonly realize institutional achievement. The description of OCB actuality cannot occur from the occupation position and official responsibility, and personnel do not obtain motivation for achieving them; this leads to the explanation why a number of searchers classify organizational citizenship behavior (OCB) as the conception of Further task Activities (Turek and Turek, 2015, 3).

Organ (1988) explored five particular dimensions of organizational citizenship behavior (OCB) as the following:

(1) Altruism: is aimed at other workers nevertheless donating to grouping capabilities through enhancing personnel's' performance; associates assist new peers and provide freely of their time.

(2) Conscientiousness: is the considerate utilized of time to increase the competences of mutually individuals and the team; members offer extra time to the association and apply attempts further than the formal requirements.

(3) Sportsmanship: expanding the total time which is spent on institutional activities; workers reduce time spent on unreasonable actions and complaining.

(4) Courtesy: avoiding troubles and improving facilitates productive exploit of time; workers present advanced notifications, appropriate reminders and proper information.

(5) Civic virtue: encouraging the benefits of the association commonly; workers willingly engage on teams or working groups and pay attention to functions.

OCB has been a topic of concentration of researchers for more than 25 years. A number of measurements of OCB have been discussed by many researchers. As well as there were diverse aspects of OCB, there are also varied purposes intended for performing OCB. A number of scales are also initiated infrequently to determine dimensions of OCB for instance: Podsakoff, Mackenzie, Moorman and Fetter (1990) adopted the same five 
dimensions of organ as mentioned above. This study adopted the five dimensions of OCB given by Organ and refers to other dimensions discussed by various scholars.

Podsakoff et al., (2014) expressed OCB as "voluntary assisting activities which do not essentially engage the requirement of organizational dilemma for the behavior to occur from the volunteer, on the other hand it necessitate the willingness and collaborating to help other workers".

\section{Methodology of the Study}

The current study is considered as Descriptive and Analytical study, since it aims to investigate the impact of career path development on organizational citizenship behavior in Greater Amman Municipality.

This study is essential in terms of style (Basic) and applied in greater Amman municipality where the purpose of illustration (Explanatory), Deductive in its nature, as it depends on management theories and previous studies.

\subsection{Population and Sample}

The targeted population of this study was all managers at the middle level in Greater Amman Municipality (at the main center), the population size was (122) managers.

A simple random sampling was used to select the study's sample. The sample size was (90) respondents were targeted. To collect the primary data (90) questionnaires were distributed to them, out of which (85) questionnaires were retrieved and only (82) questionnaires were valid for statistical analysis, indicating response rate of $(91 \%)$ valid for the analysis.

\subsection{Unit of Analysis}

The unit of analysis consists of all managers who are located in the middle managerial level in Greater Amman Municipality.

\subsection{Data Collection}

Two sources of data collection were used in this study: Primary and Secondary data:

$\checkmark$ Secondary data: Data was collected from different sources such as journals, researches, thesis, articles, books, and the internet that related to the study's topic. The different data and references were documented according to the American Psychological Association system (APA, 2010).

$\checkmark \quad$ Primary data: A questionnaire was designed to collect primary data about all the study's variables and demographic characteristics of the study's sample in Greater Amman Municipality.

\subsection{Instrument of the Study}

The questionnaire consists of three parts can be shown appendix (1), which are:

* First part: showed the demographic dimensions related to: (Gender, Age, Academic Qualification, and Experience).

* Second part: includes all statements that measure study's variables.

$>$ Independent variable (career path development which was measured by (20) items.

$>$ Dependent variable (organizational citizenship behavior which was measured by (10) items, based on organ (using Likert scale of five scores: strongly agree, agree, neutral, disagree, and strongly disagree).

\subsection{Validity}

To test study's questionnaire for clarity and to provide coherent study questionnaire; and to ensure that questionnaire measures what it has designed to measure, the questionnaire had been sent to a number of academic reviewers from universities who specialized in Business Administration. Some items were added, while others were dropped based on the reviewers' recommendations.

\subsection{Reliability}

Cronbach's alpha was used to determine the internal consistency reliability of the elements. Reliability should be $(0.60 \%)$ or higher to indicate adequate convergence or internal consistency (Sekaran \& Bougie, 2010, 184 ). Table (1) showed that reliability coefficients for all items were above $0.60 \%$ used in the current study. The reliability coefficients for all the items ranged from (873 to 924). Hence, the current study's questionnaire items were all of reasonable satisfactory reliability. 
Table 1. Reliability coefficients / Cronbach's Alpha

\begin{tabular}{lcc}
\hline Variables & No. of Items & Cronbach's Alpha \\
\hline Career management & 11 & .922 \\
Career planning & 9 & .924 \\
Career development & 20 & .911 \\
OCB & 10 & .873 \\
\hline
\end{tabular}

\section{Data Analysis and Testing the Hypothesis}

\subsection{Demographic Variables of the Study Sample}

The following Table 2 presents the demographic variables of the study which includes (gender, age, Academic qualification, Years of Experience).

Table 2. Distribution of the sample according to demographic variables $(\mathrm{n}=82)$

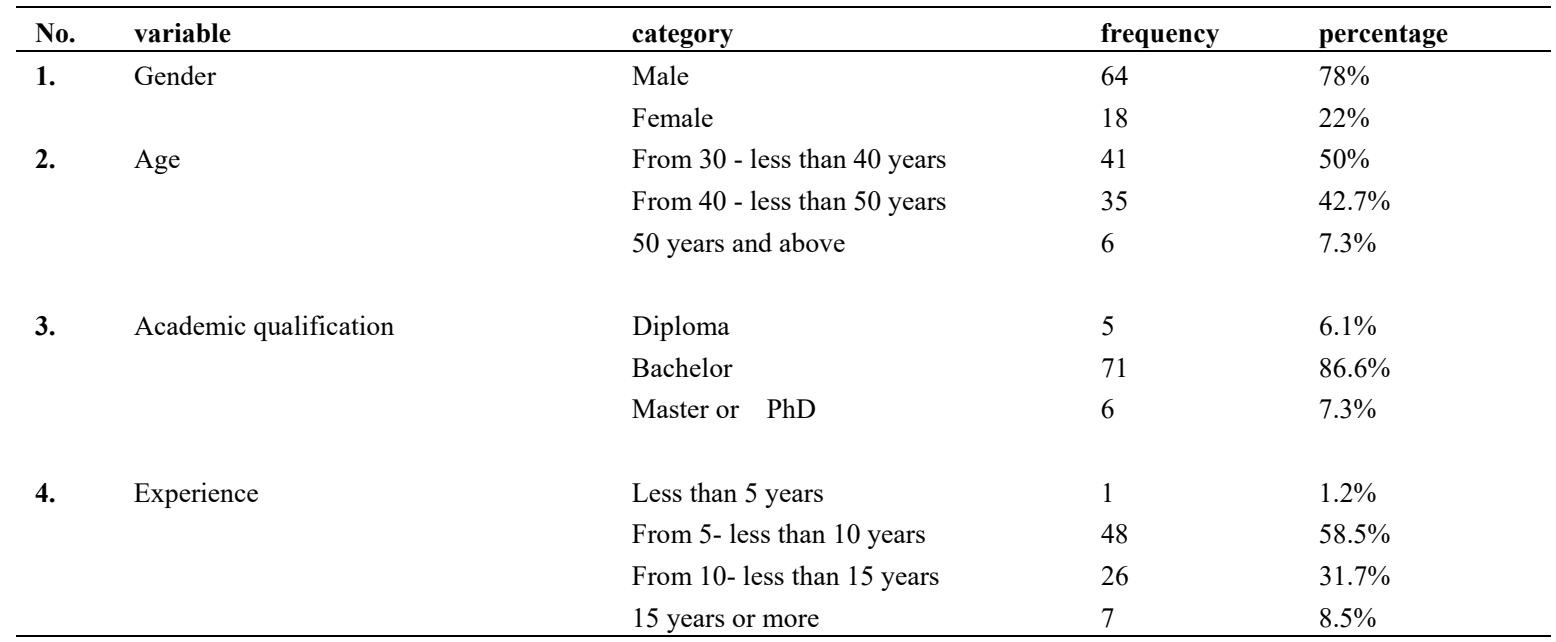

Table 2 shows the general characteristics of the respondents in terms of gender, age, academic qualification, position, department, and experience:

* Gender: It appears that most respondents are male with 64 (78\%) while the female is 18 respondents $(22 \%)$ which represent the nature of the Jordanian community.

* Age: It is clear that the most respondent ages are between 30 and less than 40 years old (50\%), while the least respondent ages are between 50 years old and above $(7.3 \%)$. This indicates that the Jordanian community is youth in characteristics.

* Academic qualification: It appears that the most respondents have Bachelor degree with 71 respondents $(86.6 \%)$, while the least academic qualification degree is diploma with 5 respondents $(6.1 \%)$. This entails the need for higher degree in academic qualification especially in higher level positions.

* Experience: It's obvious that most respondent years of experience are from 5- less than 10 years with 48 respondents $(58.5 \%)$, while the least years of experience are Less than 5 years with 1 respondent $(1.2 \%)$.

\subsection{Descriptive Analysis for the Independent and Dependent Variables}

The descriptive data for variables that designed study model can be shown. All means were above the mid-point of 2.5/5 and the majority of the variables were classified (High). The outcomes illustrate that the largest part of respondents affirm generally positive responses to the variables entered in the research model. The findings also demonstrate the "importance" degree and the category for each item in the questionnaire, which mostly were high.

\subsection{Testing the Hypothesis}

$\mathrm{H}_{\mathrm{O}}$ 1: There is no a statistically significant impact at level $(\mathrm{P}<=0.05)$ of career path development with its dimensions: (career planning and career management) on organizational citizenship behavior (OCB) in Greater Amman Municipality. 
To test this hypothesis, the study uses the multiple regression analysis to ensure the impact of career path development with its dimensions: (career planning and career management) on organizational citizenship behavior (OCB) in Greater Amman Municipality.

Table 3. Multiple regression analysis to ensure the impact of career path development with its dimensions on organizational citizenship behavior (OCB) in Greater Amman Municipality

\begin{tabular}{|c|c|c|c|c|c|c|c|c|c|}
\hline & (R) & $\left(\mathbf{R}^{2}\right)$ & $\begin{array}{c}\text { F } \\
\text { calculate }\end{array}$ & DF & Sig* & Indepe-V & Beta & $\begin{array}{l}T \\
\text { calculate }\end{array}$ & Sig* \\
\hline \multirow[t]{4}{*}{ OCB } & 0.812 & 0.659 & 76.202 & 2 & 0.000 & Career planning & 0.444 & 6.702 & 0.000 \\
\hline & & & & 80 & & & & & \\
\hline & & & & & & Career management & 0.736 & 11.113 & 0.000 \\
\hline & & & & 81 & & & & & \\
\hline
\end{tabular}

* The impact is significant at level $(\mathbf{P}<=0.05)$.

Table 3 shows that the impact of career path development with its dimensions on organizational citizenship behavior (OCB) in Greater Amman Municipality. The regression model achieve a high degree of fit, as reflected by "R" $(0.812)$ and "R2" value $(0.659)$, which asserted that $(65.9 \%)$ of the explained variation in organizational citizenship behavior in Greater Amman Municipality can be accounted for career path development with its dimensions: (career planning and career management). As well as Table (3) shows that the analysis of variance of the fitted regression equation is significant with Analysis of variance Show that $(\mathrm{F}=76.202)$, with (Sig. $=$ $0.000)$, on $(\mathrm{DF}=2)$, which means that a significant regression. It is seen from the Coefficient table that (beta $=.444),(\mathrm{t}=6.702)$, at $(\mathrm{Sig} .=0.00)$ for career planning; also for career management, (beta $=.736),(\mathrm{t}=11.113)$, at (Sig. $=0.00$ ), this confirms that A significant Coefficient, for career path development. Since the p-value is less than (0.05), it shows a statistically significant impact between the variables at (0.95) confidence level.

This further supported the study's first alternate hypothesis. There is a statistically significant impact at level $(\mathbf{P}<=0.05)$ of career path development with its dimensions: (career planning and career management) on organizational citizenship behavior (OCB) in Greater Amman Municipality.

HO1-1: There is no a statistically significant impact at level $(\mathrm{P}<=0.05)$ of career planning on organizational citizenship behavior (OCB) in Greater Amman Municipality.

To test this hypothesis, the researcher uses the Simple regression analysis to ensure the impact of career planning on organizational citizenship behavior (OCB) in Greater Amman Municipality. As shown in Table (4).

Table 4. Simple regression analysis to ensure the impact of career planning on organizational citizenship behavior (OCB) in Greater Amman Municipality

\begin{tabular}{|c|c|c|c|c|c|c|c|c|c|}
\hline & (r) & $\left(r^{2}\right)$ & F calculate & DF & Sig* & & Beta & T calculate & Sig* \\
\hline OCB & 0.682 & 0.458 & 69.393 & 1 & 0.000 & $\begin{array}{l}\text { Career } \\
\text { planning }\end{array}$ & 0.682 & 8.330 & 0.000 \\
\hline
\end{tabular}

* The impact is significant at level $(\mathbf{P}<=0.05)$.

Table 4 shows that the impact of career planning on organizational citizenship behavior (OCB) in Greater Amman Municipality. The regression model achieve a high degree of fit, as reflected by " $R$ " and" $R 2$ " value $(0.682),(0.458)$, which asserted that $(45.8 \%)$ of the explained variation in organizational citizenship behavior (OCB) in Greater Amman Municipality can be accounted for career planning. As well as Table (4) shows that the analysis of variance of the fitted regression equation is significant with Analysis of variance Show that $(\mathrm{F}=$ 69.393), with $(\mathrm{Sig} .=0.000)$, on $(\mathrm{DF}=1)$, which means that a significant regression. It is seen from the Coefficient table that (beta $=.682),(\mathrm{t}=8.330)$, at $(\mathrm{Sig} .=0.00)$, this confirms that A significant Coefficient, for career planning. Since the p-value is less than $(0.05)$, it shows a statistically significant impact between the variables at $(0.95)$ confidence level.

This further supported the first alternate sub-hypothesis.

There is a statistically significant impact at level $(\mathbf{P}<=0.05)$ of career planning on organizational 
citizenship behavior (OCB) in Greater Amman Municipality.

HO1-2: There is no a statistically significant impact at level $(\mathrm{P}<=0.05)$ of career management on organizational citizenship behavior (OCB) in Greater Amman Municipality.

To test this hypothesis, the researcher uses the Simple regression analysis to ensure the impact of career management on organizational citizenship behavior (OCB) in Greater Amman Municipality.

Table 5. Simple regression analysis to ensure the effect of career management on organizational citizenship behavior (OCB) in Greater Amman Municipality

\begin{tabular}{llllllllll}
\hline & $(\mathbf{r})$ & $\left.\mathbf{r}^{2}\right)$ & $\begin{array}{c}\mathbf{F} \\
\text { calculate }\end{array}$ & DF & Sig* & & Beta & $\begin{array}{l}\text { T } \\
\text { calculate }\end{array}$ & Sig* $^{*}$ \\
\hline OCB & 0.353 & 0.125 & 76.202 & 1 & 0.000 & $\begin{array}{l}\text { Career } \\
\text { management }\end{array}$ & 0.353 & 3.379 & 0.000 \\
\hline
\end{tabular}

* The impact is significant at level $(\mathbf{P}<=0.05)$

Table 5 shows that the impact of career management on organizational citizenship behavior (OCB) in Greater Amman Municipality. The regression model achieve a high degree of fit, as reflected by " $R$ " and" $R 2$ " value $(0.353),(0.125)$, which asserted that $(12.5 \%)$ of the explained variation in organizational citizenship behavior (OCB) in Greater Amman Municipality can be accounted for career management. As well as Table (5) shows that the analysis of variance of the fitted regression equation is significant with Analysis of variance Show that $(\mathrm{F}=76.202)$, with $(\mathrm{Sig} .=0.000)$, on $(\mathrm{DF}=1)$, which means that a significant regression. It is seen from the Coefficient table that (beta $=.353)$, $(\mathrm{t}=3.379)$, at $(\mathrm{Sig} .=0.00)$, this confirms that A significant Coefficient, for career management. Since the p-value is less than (0.05), it shows a statistically significant impact between the variables at $(0.95)$ confidence level.

This further supported the first alternate sub-hypothesis.

There is a statistically significant impact at level $(P<=0.05)$ of career management on organizational citizenship behavior (OCB) in Greater Amman Municipality.

\section{Findings}

The main objective of this study is to examine the impact of career path development on organizational citizenship behavior in greater Amman municipality. The study developed theoretical framework based on the previous study. The multiple regression analysis shows that there is statistically significant impact of career path development (career planning and career management) on OCB in greater Amman municipality; respondents at middle managerial level assumed that there was a strong consistent and strong association between the two independent variables and organizational citizenship behavior.

The current study revealed a set of results

* Demographic Characteristics of the Respondents Out of a set of eighty two (82) questionnaires that were directed to greater Amman municipality. The detailed analysis of the demographic characteristics of the respondents is therefore, presented that the ratio of males has reached (78\%), as also shown that the largest percentage $(86.6 \%)$ of the sample are of the bachelor's holders. It turns out that the category (30- less than 40 years) is the largest category that reached (50\%).with regard to the experience, it was shown that $(58.5 \%)$ of the respondents have experiences from (5 to less than 10 years).

* There is a statistically significant impact at level $(\mathbf{P}<=0.05)$ of career path development with its dimensions: (career planning and career management) on organizational citizenship behavior (OCB) in Greater Amman Municipality.

This result is consistent with the result of Kimani and Gachunga (2013) study that explored the influence of career management practices on employee engagement. And it concluded that there is an impact of career management practices: (mentoring, job posting, career planning, and performance review) on employee engagement. Career path development may contribute to organizational citizenship behavior (Organ, Podsakoff \& MacKenzie, 2006; Snape \& Redman, 2010; Fu, 2013).

This result is varying with the result of Turek and Turek (2015) study that described and explained how the human resource management practices and person organizational fit (P-O fit) are related to organizational citizenship behavior (OCB). The study reached that there is a significant correlation between all studied variables. 
The study also concluded that employees' citizenship behaviors form an important factor creating the overall effectiveness of an organization.

This result is consistent with the result of Okurame (2012) study that explored when employees notice broad prospects for their professional career development, and they know that the organization is able to deliver on its promises concerning their careers; they try to reciprocate such gestures by a high quality of their work and an appropriate behavior. One method of such behavior is OCB. Creating professional development opportunities for an employee increases the likelihood that the employee will behave in accordance with OCB. On the other hand, if employees notice that promises of a professional development policy are inconsistent with their expectations, i.e. when the organization makes certain commitments to employees, and then fails to comply with them, in consequence the employees neglect their work and only fulfill the duties they are formally designated to perform.

* There is a statistically significant impact at level $(\mathbf{P}<=0.05)$ of career planning on organizational citizenship behavior (OCB) in Greater Amman Municipality.

Results also indicated that career planning (individual responsibility) had a significant impact on OCB in greater Amman municipality. It therefore, implies that the higher level of planning the individual career by the individual responsibility.

* There is a statistically significant impact at level $(\mathbf{P}<=0.05)$ of career management on organizational citizenship behavior (OCB) in Greater Amman Municipality.

This result indicated that results also indicated that career management (organizational responsibility) had a significant impact on OCB in greater Amman municipality. This implies that greater Amman municipality provided career management processes the sufficient importance and arrangements.

This result is consistent with Shujaat, Aftab, Sana, and Ahmed (2013) study examined the relationship between career development and job satisfaction. The study is focusing on private banks in Karachi. The study reached that there is a positive relationship between career development and job satisfaction.

\section{Recommendations}

$\checkmark$ It is important for Greater Amman Municipality to recognize the needs of its individuals in career path planning and offer mentoring sittings to assist them shape their career; by helping them in developing career goals and also in accomplishing those aspirations.

$\checkmark$ The necessity of helping employees to determine their development requires rooted in self assessment. Organizations create an environment for continual learning by supporting and rewarding employee development.

$\checkmark$ Assisting the associations in developing sequence plans for the crucial positions in the association.

$\checkmark$ The necessity for providing all the programs and inducements that improving organizational citizenship behavior such as justice of promotion and compensations, training, and improve quality of work life.

$\checkmark$ Organization should use compensation strategies that support the organizational career development strategy and enhancing the OCB.

\section{References}

Antoniu, E. (2010). Career Planning Process and its Role in Human Resource Development. Annals of the University of Petroşani, Economics, 10(2), 13-22.

Anwar, A.,\& Gani, O. (2015). The Effects of Spiritual Intelligence and its Dimensions on Organizational Citizenship Behaviour. Journal of Industrial Engineering and Management JIEM, 8(4), 1162-1178. http://dx.doi.org/10.3926/jiem.1451

Aslefallah, H., \& Badizadeh, A. (2014). Effect of Organizational Citizenship Behaviour on Total Quality Management and Organizational Performance (Case study: Dana Insurance Co.). European Online Journal of Natural and Social Sciences, 3(4), 1124-1136.

Bernardin, H. J. (2010). Human Resource Management: An Experential Approach (5 ${ }^{\text {th }}$ ed.). MCGRAW HillInternational. Edition.

Cascio, W. (2013). Managing Human Resources (Productivity, Quality, Profit). MCGRAW Hill- International. Edition.

Cascio, W. F. (2006). Managing Human Resource: Productivity, Quality of Life, Profits. McGraw- Hill Irwin. 
Chebet, K. (2015). Career Planning and Succession Management Practices of the Clinicians at Kenyatta National Hospital. Research Project of Degree Master of Science in Human Resource Management, School OF BUSINESS, UNIVERSITY OF NAIROBI.

Chelagat, L., Chepkwony, P. K., \& Kemboi, A. (2015). Effect of Organizational Citizenship Behavior on Employee Performance in Banking Sector, Nairobi County, Kenya. International Journal of Business, Humanities and Technology, 5(4), 55-61.

Dessler, G. (2012). Human resource management (13th ed.). Pearson Education.

Durai, P. (2010). Human Resource Management (10th ed.). pearson.

Fu, Y. K. (2013). High-performance human resource practices moderate flight attendants'organizational commitment and organizational citizenship behavior. Social Behavior and Personality, 41, 1195-1208.

Huak, M., \& Pivi, F. (2015). The Impact of Organizational Citizenship Behavior on Employee's job satisfaction, commitment and turnover intention in Dining Restaurants Malaysia. International Journal Accounting, Business, and Management, 1(1), 1-17.

Kaya, C., \& Ceylan, B. (2014). An Empirical Study on the Role of Career Development Programs in Organizations and Organizational Commitment on Job Satisfaction of Employees. American Journal of Business and Management, 3(3), 178-191. http://dx.doi: 10.11634/216796061403551.

Kimani, J. N., \& Gachunga, H. G. (2013). Influence of career management practices on employee engagement: A case study of civilian staff at the Ministry of Defense in Kenya. International Journal of Social Sciences and Entrepreneurship, 1(7), 316-339.

Mushraf, A. M., Al-Saqry, R. H., \& Obaid, J. (2015). The Impact of Big Five Personality Factors on Organizational Citizenship Behaviour. International Journal of Management Science, 2(5), 93-97.

Noe, R. A., Hollen, B., John, R., Gerhrty, B., \& Wright, P. M. (2012). Fundamentals of human resource management (4th ed.). Boston: Mc Graw-Hill.

Okurame, D. (2012). Impact of career growth prospects and formal mentoring on organizational citizenship behaviour. Leadership \& Organization Development Journal, 33(1), 68-85.

Organ D. W., \& Ryan, K. (1997) A meta-analytic review of attitudinal and dispositional predictors of organizational citizenship behavior. Personnel Psychology, 48(4), 775-802.

Organ, D. W. (1988). Organizational Citizenship Behavior: The Good Soldier Syndrome. Lexington MA: Lexington Books.

Organ, D. W., Podsakoff, P. M., \& MacKenzie, S. B. (2006). Organizational citizenship behavior: Its nature, antecedents, and consequences. Thousand Oaks, CA: Sage.

performance: A multi-level analysis. Journal of Management Studies, 47, 1219-1247.

Podsakoff, N. P., Podsakoff, P. M., MacKenzie, S. B., Maynes, T. D., \& Spoelma T. M. (2014). Consequences of unit-level organizational citizenship behaviors: A review and recommendations for future research. Journal of Organizational Behavior, 35, 87-119.

Podsakoff, N. P., Whiting, S. W., Podsakoff, P. M., \& Mishra, P. (2011). Effects of organizational citizenship behaviors on selection decisions in employment interviews. Journal of Applied Psychology, 96, 310-326.

Priyanka, S., \& Sripirabaa, B. (2016). Assessing the Impact of Organizational Citizenship Behaviour on Intention To Stay Among Bank Employees in Coimbatore District. Indian Journal of Research, 5(4), $140-144$.

Robbins, S., \& Coulter, M. (2009). Management (11th ed.). Prentice Hall.

Sekaran, U., \& Bougie, R. (2010). Research methods for business: A skill-building approach (5 ${ }^{\text {th }}$ ed.). New York, NY: John Wiley \& Sons Inc.

Sharma, P., Bajpai, N., \& Holani, U. (2011). Organizational Citizenship Behavior in Public and Private Sector and Its Impact on Job Satisfaction: A Comparative Study in Indian Perspective. International Journal of Business and Management, 6(1).

Sharma, V., \& Jain, S. (2014). A Scale for Measuring Organizational Citizenship Behavior in Manufacturing Sector. Pacific Business Review International, 6(8), 57-62.

Singh, C. (2011). Human Resource Management. University Science Press. 
Snape, E., \& Redman, T. (2010). HRM practices, organizational citizenship behavior.

Stewart, G., \& Brown, K. (2011). Human Resource Management- Linking Strategy to Practice (2nd ed.). John Wiley \& Son Inc.

Turek, D., \& Turek, A. (2015). HRM practices Influences organizational citizenship behaviors (OCB person-organization? Mediating the Role of person-organization fit. Management, Learning, and Knowledge conference, Italy-Roma. Proceeding Book of Conference.

\section{Copyrights}

Copyright for this article is retained by the author(s), with first publication rights granted to the journal.

This is an open-access article distributed under the terms and conditions of the Creative Commons Attribution license (http://creativecommons.org/licenses/by/4.0/). 